\title{
Menganalisis Informasi Metaverse Pada Game Online Roblox Secara Garis Besar
}

\author{
Ii Sopiandi, Deffy Susanti \\ Universitas Majalengka, Fakultas Teknik, Prodi Informatika \\ iisopiandi@unma.ac.id, dfy@unma.ac.id
}

\begin{abstract}
Abstrak: Perkembangan teknologi yang semakin maju disetiap lini baik dalam dunia industry, Pendidikan ataupun dunia games,membuat orang berlomba-loba dalam perkembanganya untuk menjadi yang terbaik, metaverse adalah bagian dari internet yang dimana didalamnya dibuat sedemikian rupa menyerupai dunia nyata, metaverse dalah ruang virtul untuk berkomunikasi dengan sesama dalam suatu tempat tertentu di dunia virtual, terutama dalam game online begitu banyaknya game yang menjamur sehingga metavere adalah salah satu tempat berkumpulnya para gameres di seluruh lapisan dunia yaitu berada di metaverse.
\end{abstract}

Kata Kunci : Metaverese; game online; Informasi.

Abstract: Technological developments that are increasingly advanced in every line both in the world of industry, education or the world of games, make people compete in their development to be the best, metaverse is part of the internet which is made in such a way as to resemble the real world, metaverse is a virtual space to communicate with each other in a certain place in the virtual world, especially in online games so many games are mushrooming that metavere is one of the gathering places for gamers in all walks of life, namely in the metaverse.

Keywords: Metaverese; online games; Information

\section{Pendahuluan}

Diabad modern yang serba canggih dan membutuhkan teknologi yang mumpun membuat orang-orang baik pengembang ataupun pengguna berlomba-loba dalam membeli atau menciptakan teknologi tepat guna dalam hal membantu pekerjaanya dan kegiatan-kegiatan lainnya, dan salah satunya adalah lahirnya metaverse

Metaverse ini awalnya di tuangkan pada novel fiksi ilmiah karya neal Stephenson pada tahun 1992 yang berjudul snow crash, dimana diceritakan manusia mempunyai avatar tersendiri, setiap avatar bisa melakukan interaksi satu sama lain dalam sebuah perangkat lunak tiga dimensi Metaverse adalah realitas digital yang menggabungkan aspek media sosial, game online, augmented reality (AR), virtual reality (VR), dan cryptocurrency untuk memungkinkan pengguna berinteraksi secara virtual.dimetaverse kita sebenernya bisa melakukan banyak hal, seperti pada umumnya berkumpul dengan teman teman virtual baik teman baru dikenal ataupun teman lama, berkumpul dengan keluarga jauh, kita bisa melakukan pekerjaan, melakukan belajar secara virtual, bermain, melakukan belanja secara virtual, melakukan ekpermimen berkreasi dengan pengalaman pengalaman baru yang dimana polanya aga sedikit berbeda dengan penerapan computer saat ini, dimasa depan manusia tidak akan dibingungkan bekerja harus tepat dating ketempat, sebab manusia bisa berteleportasi menjadi hologram instan dan langsung 
berada di kantor tanpa perjalanan yang melelahkan, bisa mengikuti konser dengan teman temanya tanpa harus di ribetkan beli tiket ditempat dan lain -lainya. Internet sudah sangat sukses menghubungkan orang- orang di segala dunia satu sama lain serta berperan selaku semacam Bibliotek Alexandria modern buat menaruh banyak sekali pengetahuan. Tetapi itu pula sudah tingkatkan privatisasi ruang publik, serta mengundang iklan ke tiap sudut kehidupan kita, mengikat kita ke segelintir industri raksasa yang lebih kokoh daripada banyak negeri, serta menimbulkan dunia virtual memakan dunia raga lewat kehancuran area. Jadi metaverse itu dunia komunitas virtual tanpa akhir yang saling terhubung. Di mana, orang-orang dapat bekerja, bertemu, bermain dengan menggunakan headset realitas virtual, kacamata augmented reality, aplikasi smartphone dan atau perangkat lainnya. metaverse hadir bukan hanya besutan dari pihak facebook saja akan tetapi dari rival rival yang lainnya seperti microsfot dan lainya ikut andil dalam perkembangan metaverse walpun sebagain ada yang berdiri sendiri

Seperti halnya dunia games, tidak serta merta perkembanganya hanya berbasis Offline saja akan tetapi perkembangan Online juga semakin menjamur di kehidupan kita salah satu contonnya game mobile legend dan game lainnya yang semakin digandrungi oleh beberapa kalangan..di dunia games menikmati acara bisa live stream pada sebuah dunia virtual metaverse melalui contoh platform Bernama core, dalam dunia metaverse ini penonton tidak hanya dapat menyaksikan acara permainan games bergengsi , tetapi bisa melakukan banyak hal seperti menghadiri pesta Bersama para pengunjung lainnya

\section{Metode Penelitian}

Penelitian ini di lakukan pada jenis-jenis game online seperti game fortinite, Minecraft, roblox, atau second life sebab game game ini adalah literasi awaldalam dunia metaverse. Adapaun tatacara pengumpulan data yaitu dengan melakukan studi kasus langsung ke beberapa games dan situs -situs games dengan meneliti pola dan karakter games secara langsung

Adapun cara memperoleh data dengan menggunakan pendekatan data sekunder yaitu di peroleh tidak secara langsung dari sumbernya atau objek penelitian, dengan kata lain penelitian data melalui litelatur buku, journa, serch engine dan banyak hal yang mendukung dalam penelitian

\section{Hasil dan Pembahasan}

Pada hasil dan pembahasan kali ini akan di informasikan jenis game yang akan terlibat di dunia metaverse dan cara kerjanya setiap games sebagai berikut :

\section{a. Games robox}

Didirikan oleh CEO roblox Bernama David Baszucki, kenapa game ini digandanggandang akan masuk ke jajaran game online metaverse alasanya ada banyak hal karenda banyak di sukai oleh anak anak dan bahkan orang dewasa sekali pun memainkanya, game ini berbasis online dan gratis yang memungkinkan penggunanya mendesain pemainan mereka sendiri dan memainkan kreasi dari pemain lainnya. Penggunakanya lebih dari 150 juta aktif pada lebih 200 negara di dunia yang di mana pencapaian Minecraft yang mempunyai 90 juta pengguna aktif setiap bulanya. Pengguna di sugihkan berbagai macam games gratis. 
Adapun alas an kenapa game ini sangat dingemari selain grtais yaitu mudah dimainkan melalui aplikasi desktop, mobile hingga konsol games, selain itu games ini bisa di mainkan di beberapa banyak platform speeti windows, IOS, MacOS, Xbox one dan android dan banyak lagi dukunganya, banyaknya pilihan games yang menarik, dan yang lebih uniknya berbasis komunitas dan menghasilkan uang dari roblox ini berikut :

Ada beberapa cara dalam menghasilkan uang dalam games ini yaitu sebagai

a. Membuat games : developer bisa menghasilkan uang dengan cara membuat game semakin banyak orang yang memainkan, kesempatan untuk menghasilkan uang semakin besar

b. Menjual games peralatan : beberapa pengguna masih awam blum bisa memahami ataupun membuat perlengkapan seperti pakaian hingga rambut yang unik sendiri

c. Pengguna premium : bisa mnghasilkan uang jika di pengaruhi penggunananya premium

d. Penawaran purchasae : menawarkan tawaran item atau fitur premium pada games yang bisa dibeli oleh penguna

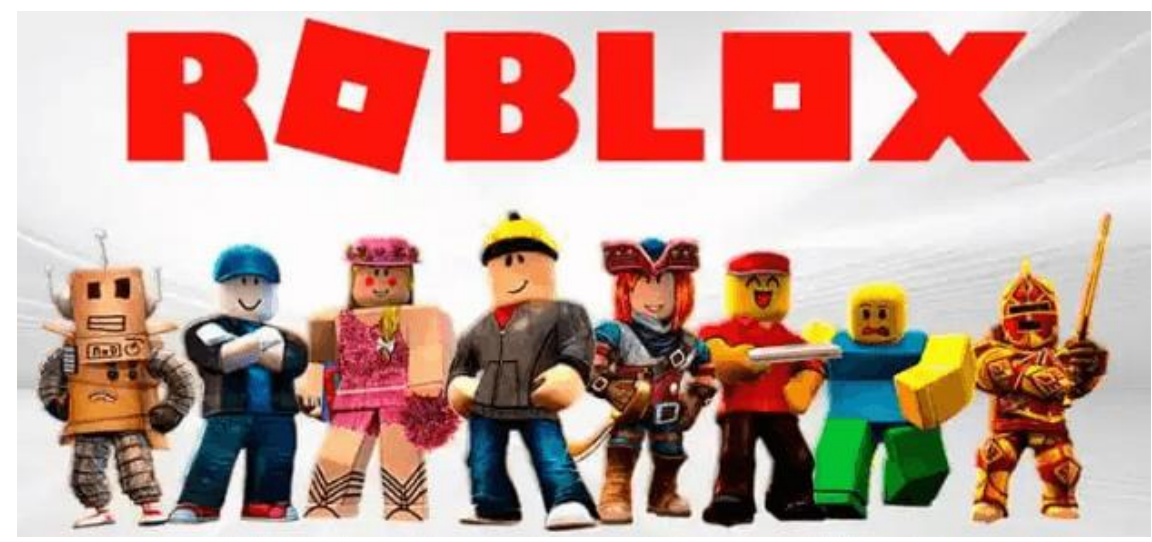

Gambar 1 : contoh ilustrasi games roblox

\section{b. Pengguna bisa berkomunikasi di dunia virtual metaverse}

Karena dukungan komunitas yang sangat besar dan beberapa tutorial online dalam mempelajari permainan roblox sendiri dengan Bahasa pengodean yang sangat muda dan difahami oleh anak anak sekalipun jadi intinya pengguna selain bisa bermain dan bisa berkreasi dalam keterlibatan pembuatan gamenya sendiri

\section{c. Peluang bisnsis voucher Games}

Beigtu menjamurnya voucher game diberbagai kalangan salah satunya adalah fastpay membuka kesempatan menjadi agen voucher games di bergagai dunia games sehingga roblox merupakan pilihan yang tepat ikut andil dalam dalam bisnis ini. Selain itu bukan hanya 


\section{Kesimpulan dan Saran}

Didunia games sekarang tidak ada yang tidak mungkin kita bisa melakukan banyak hal, selain kita bisa bermain games di dalamnya kita bisa ikut andil dalampenciptaan games sendiri. Dengan adanya metaverse orang orang bisa membangun jaringan di dunia games dan berkomunikasi secara virtual hologram dan membangun bisnis sendiri dalam menghasilkan uang.

\section{Daftar Pustaka}

Joshua, J. (2017). Information Bodies: Computational Anxiety in Neal Stephenson's Snow Crash. Interdisciplinary Literary Studies, 19(1), 17-47.

North of 41 (2020). What really is the difference between AR / MR / VR / XR? Access Date: 15/12/2021 https://medium.com/@northof41/what-really-is-the-difference-between-ar-mr-vrxr-35bedldala4e

Milgram, Paul \& Kishino, Fumio. (1994). A Taxonomy of Mixed Reality Visual Displays. IEICE Trans. Information Systems. vol. E77-D, no. 12. 1321-1329.

Thomas, P. C., \& David, W. M. (1992, January). Augmented reality: An application of headsup display technology to manual manufacturing processes. In Hawaii international conference on system sciences (pp. 659-669).

Fast-Berglund, Å., Gong, L., \& Li, D. (2018). Testing and validating Extended Reality (xR) technologies in manufacturing. Procedia Manufacturing, 25, 31-38.

Huang, T. S. (1996). Computer vision: Evolution and promise. CERN European Organization for Nuclear Research-Reports-CERN, 21-26.

Marr, D. (1982). Vision: A computational investigation into the human representation and processing of visual information, henry holt and co. Inc., New York, NY, 2(4.2).

Huang, T. S. (1996). Computer vision: Evolution and promise. CERN European Organization for Nuclear Research-Reports-CERN, 21-26.

Marion Davies (2021). Pros and Cons of the Metaverse. Access Date: 15/12/2021. https://www.konsyse.com/articles/pros-and-cons-of-the-metaverse/

Lee, L. H., Braud, T., Zhou, P., Wang, L., Xu, D., Lin, Z., ... \& Hui, P. (2021). All one needs to know about metaverse: A complete survey on technological singularity, virtual ecosystem, and research agenda. arXiv preprint arXiv:2110.05352. 